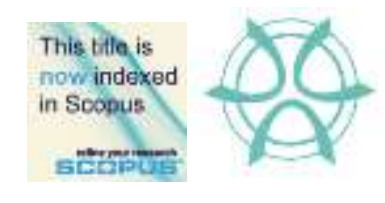

\title{
ROUTE PLANNING FOR CROWD MANAGEMENT IN DISASTER PRONE AREAS
}

\author{
Mohammad Zarif Mohd Zahari' ${ }^{1}$, Nur Afiqah M. Zulkifli ${ }^{2}$, Muhammad Rijal \\ Mohamad $^{3}$, Oladejo Aliu Olabayonle ${ }^{4}$, Nur Athifah A. Kadir ${ }^{5}$ and Syahriah \\ Bachok $^{6}$ \\ ${ }^{1,2,3,4,5,6}$ Kulliyyah Of Architecture and Environmental Design (KAED) \\ INTERNATIONAL ISLAMIC UNIVERSITY MALAYSIA (IIUM)
}

\begin{abstract}
Managing crowd is essential in a time of emergency because a large volume of movements or flow may be restricted or obstructed by the existing capacity. This paper centres around preparedness, actions were taken during the event and mitigation measures of flooding in two case studies. Hulu Langat and Cameron Highlands have similarities and differences in planning for, managing of and reviving from flood disasters. In particular, route planning is focused to extract the movement behaviour among people impacted by the calamity. This study employed an interview method which results have been synthesised to feed into the formulation of future strategies for access or movement facilities for victims of disasters.
\end{abstract}

Keyword: Route Planning, Crowd Control, Disaster Management

\footnotetext{
${ }^{1}$ Master Student. Email: zarifkool@gmail.com
} 
Mohd Zahari, M.Z., M. Zulkifli, N.A., Mohamad, M.R., Olabayonle, O.A., A. Kadir, N.A., Bachok, S.

Route Planning for Crowd Management in Disaster Prone Areas

\section{INTRODUCTION}

Planning a route is an essential part of the transportation strategy. Time and cost are important factors determining the decision of pathways to be taken, time taken to complete the travel, in normal circumstances (Bast, Delling, Goldberg, MüllerHannemann, Pajor, Sanders, Wagner, \& Werneck, 2016). However, when faced with various circumstances such as unfamiliarity, urgency, crowding and bottlenecks, other external factors would influence such decisions that irregularity and abnormality are maybe evident in the pattern and distribution of pathways and travel time (Bast et al., 2016). Crowding is triggered when overcapacity occurs especially at bottleneck areas such as junctions or intersections (Khalid \& Yusof, 2018). This paper highlights the crowding events experienced by two localities in Malaysia coping with natural disasters. Selection of Kajang, Hulu Langat in Selangor and Lembah Bertam, Cameron Highlands in Pahang exemplifies the challenges faced by disaster-prone areas in managing the crowds during and after the calamities.

\section{RESEARCH BACKGROUND}

The National Disaster Management and Relief Committee (NDMRC) of Malaysia is the responsible authority regulating all relief activities before, during and post-disaster (Chong \& Kamarudin, 2018). Meanwhile, policies and directives are set by a Prime Minister's Department known as the National Security Council (Majlis Keselamatan Negara, MKN) and executed by the National Disaster Management Agency (NADMA) (Chong \& Kamarudin, 2018). Among the concerns regarding flooding or other disasters are the search and rescue activities, coordinating the assembly of crowds and relocating victims as well as ensuring the well-being, welfare and revival of the population following the impacts of the calamity. Preparing for disaster is currently the responsibility of agencies with designation and roles under the law (McEntire \& Myers, 2004). However, the participation of the public or local community would minimise coordination effort and increase the effectiveness of relocation during the events. ( Mohd, Fathi, Harun, \& Chong, 2018). Identification of access points and rescue centres are essential, as much as the routes or pathways connecting these places. Roads, pathways or any transportation channels must not be disrupted, intersections or junctions must not be obstructed, and conditions of the paving must not be degraded too much that movement or flow cannot pass through smoothly and efficiently. Assistance must be transported and timely rendered so that victims receive the help and necessities, to increase probabilities of revival and resuming lives as normal just like before the disaster struck. Mitigation measures must be appropriately strategized to improve and protect the areas from the recurring and extended negative impacts of the disaster (Handmer and Dovers, 1996). 
While various literature has focused on legislative and application of MKN Directives 19-21 at the Federal and State levels; the lowest level (local community) preparedness and mitigations have been less documented (Khalid and Shafiai, 2015; Mat Said and Ahmadun, 2007). Thus, this effort of mainstreaming the institutional mechanism and risk-informed community at the lowest level of administration in Malaysia aims at assisting in strengthening the disaster preparedness among the population of flood-prone areas and other relevant stakeholders.

\section{METHODOLOGY}

This study adopted qualitative methodologies of research. It employed the face to face communication method to capture primary data. The instruments utilised were audio and visual recordings of conversation based on semi-structured and general queries on the flood disaster preparation, first-hand experience dealing with flood and mitigation measures following the events. Data was collected between the month of August and November of 2019. Two case study were selected namely the districts of Cameron Highlands and Hulu Langat. Chief Assistant District Officers (CADO) of both districts were interviewed. Interview topics were focused on significant flooding events up to December 2018, which fall under the category of Level 1 based on MKN's definition. Flooding of smaller scale, such as flash flood due to a clogged drainage system, does not carry the weightage required for MKN's Level 1 disaster. Any recurring event beyond this date has not been considered during the interview sessions. Likewise, any preparation, search and rescue actions, as well as mitigation and revival activities beyond December 2018, are out of the scope of this paper.

\section{FINDINGS AND DISCUSSION}

Cameron Highlands is Pahang district of 35,000 people (DOS, 2010) living in a $712 \mathrm{~km}^{2}$ of highland areas, at an elevation of 1,400 meters from the sea level $\left(4^{\circ} 30^{\prime} \mathrm{N} 101^{\circ} 30^{\prime} \mathrm{E}\right)$. It is located some $200 \mathrm{~km}$ northeast of Kuala Lumpur. Hulu Langat is a Selangor district of 1.1 million population (DOS, 2010), residing in $840 \mathrm{~km} 2$ of mixed urban and suburban townships, located in the south-eastern border of Kuala Lumpur.

Both Cameron Highlands (CH) and Hulu Langat (HL) districts are experiencing flooding frequently but for various reasons. Some are the results of normal rainfall over longer than the usual duration. Some are due to heavy rainfall over a short duration of time. In the former, land encroachment, cultivation that degraded the soil and rapid physical development along dangerous slopes are some of the compounding factors to the damaged soil that lacks permeability. In the latter, normal rainfall over normal duration but worsened by clogged drainage systems. Other man-made flooding disasters were also attributable to rapid and concentrated physical development upstream that led to irregular flow 
Mohd Zahari, M.Z., M. Zulkifli, N.A., Mohamad, M.R., Olabayonle, O.A., A. Kadir, N.A., Bachok, S.

Route Planning for Crowd Management in Disaster Prone Areas

downstream and the different scale of drainage systems. This is especially critical as some townships in Hulu Langat (downstream) bordered settlements in Negeri Sembilan, a neighbouring state (upstream) that the authorities in Selangor have no power and jurisdictions over. HL has dams constructed for water supply while $\mathrm{CH}$ has dams for hydroelectricity generation $(\mathrm{CH})$. Both districts have Orang Asli or Aboriginal people as part of their demographic composition.

The interview contents were summarised in a thematic way based on preparedness and mitigation of flooding disaster literature. Which are stated as follows; the severity of the disaster, preparing for disaster, managing the victims during and after the events, evacuation routes and factors influencing the success of evacuation and rescue efforts. The results and findings are tabulated as follow.

Table 1: Synthesis of interview questions relating to flooding preparation, management and mitigations

\begin{tabular}{|c|c|c|}
\hline \multicolumn{3}{|c|}{ (Flood) Disaster Severity } \\
\hline Variables & $\begin{array}{l}\text { Lembah Bertam/Ringlet, Cameron } \\
\text { Highlands }\end{array}$ & Kajang and surroundings, Hulu Langat \\
\hline $\begin{array}{l}\text { Rate of } \\
\text { recurrence } \\
\text { (Flash } \\
\text { Floods) }\end{array}$ & $\begin{array}{l}\text { None in the last } 3 \text { years. } \\
\text { Last one in } 2013 \text {, though there was } \\
\text { heavy rainfall over two days which } \\
\text { resulted in landslides in } 2017 \text {. }\end{array}$ & $\begin{array}{l}\text { None in the last } 3 \text { years } \\
\text { Last one in } 2013 . \\
\text { Landslide in } 2016 \text { had } 1,500 \text { victims (Hulu } \\
\text { Langat, Cheras). }\end{array}$ \\
\hline Duration & $\begin{array}{l}2 \text { to } 3 \text { days, longer due to the "dam } \\
\text { release". }\end{array}$ & $\begin{array}{l}\text { Flash flood receded after two hours in } \\
\text { Kajang City. } \\
\text { In the 1990s experienced Banjir } \\
\text { Termenung (static flooding) in Batu } 10 .\end{array}$ \\
\hline $\begin{array}{l}\text { Impacts/ } \\
\text { Damages/ } \\
\text { Loss }\end{array}$ & $\begin{array}{l}\text { Housing damages: severe damages } \\
\text { took } 2 \text { to } 3 \text { days to recover } \\
\text { (maximum compensation of RM500 } \\
\text { per household) considered as small- } \\
\text { scale disaster at the lowest } \\
\text { hierarchy, the district level. } \\
\text { Managed it independently. } \\
\text { Required assistance depended on } \\
\text { the severity level and geophysical } \\
\text { expansion, or severity of the } \\
\text { disaster. } \\
\text { If the disaster is cross-boundary, } \\
\text { assistance is required from the state } \\
\text { and federal authorities (highest level } \\
\text { of government) depends on the } \\
\text { seriousness, required extensive } \\
\text { assets, manpower deployments. } \\
\text { Damages to settlements by the } \\
\text { riverside, by the dam areas and of } \\
\text { Orang Asli. }\end{array}$ & $\begin{array}{l}\text { Severe property damages, life-threatening } \\
\text { situations and complete or total } \\
\text { vulnerability of network for } 3 \text { days or more. } \\
\text { The old drainage system at Metro Kajang } \\
\text { upgraded. Demolished shops with TOL, old } \\
\text { shophouses in Bukit Angkat strengthened } \\
\text { by retaining walls, water controlled. } \\
\text { Upgrading works of Hugo in Kampung } \\
\text { Jambu in progress. } \\
\text { Only level } 2 \text { disaster and mostly level } 1 \\
\text { disaster. No road blocked, alternative } \\
\text { routes become very long. One occasion all } \\
\text { was trapped, but there were boats. } \\
\text { Never experienced the level } 3 \text { disaster. } \\
\text { Semenyih is traditional Malay housing, } \\
\text { previously a hill but was levelled for } \\
\text { construction. No hill, wind passes easily, } \\
\text { storm. }\end{array}$ \\
\hline
\end{tabular}




\begin{tabular}{|c|c|c|}
\hline & $\begin{array}{l}\text { Land in Cameron Highlands is } \\
\text { strong (stable) and seldom fallen } \\
\text { trees occurred at the steepest of } \\
\text { slopes. } \\
\text { Small scale debris can be handled } \\
\text { locally, based on MKN } 20 \\
\text { Directive. }\end{array}$ & \\
\hline $\begin{array}{l}\text { Communicat } \\
\text { ion and } \\
\text { Access cut }\end{array}$ & $\begin{array}{l}\text { Population including the aboriginal } \\
\text { spread into the forest for } 22 \mathrm{~km} \text {. Not } \\
\text { possible to utilise only one } \\
\text { telecommunication system. Only } \\
\text { the telephone, SMS did not always } \\
\text { work. Wireless works, satellite } \\
\text { phones expensive. } \\
\text { Assistance from Cameron } \\
\text { Highlands Adventure Team } \\
\text { (CHAT). } \\
4 x 4 \text { amateur team who voluntarily } \\
\text { provided vehicles, tracking devices } \\
\text { and human resource. } \\
\text { In Habu, Kuala Terlah, CHAT } \\
\text { helped radio communication and } \\
\text { vehicles. } \\
\text { Communication breakdown due to } \\
\text { lost wireless reception. } \\
\text { Communication to improve with } \\
\text { telecommunication mast in } \\
\text { Brinchang. }\end{array}$ & $\begin{array}{l}\text { Backflow of stormwater to village drainage } \\
\text { system resulted in flooding. Panicky, } \\
\text { moved electrical appliances to higher } \\
\text { grounds. } \\
\text { Communicate with MPKK and Penghulu. } \\
\text { village leader to make headcount. } \\
\text { Police Department to evacuate and DCW to } \\
\text { counsel relocation and in the event of death. } \\
\text { Disaster Unit to use excavator, container, } \\
\text { tractor, pump, tanks. Repair toilets, } \\
\text { communal area. Lack of boats. Head } \\
\text { villager and Penghulu set up relocation } \\
\text { centres. } \\
\text { Criteria: distance, the total number and the } \\
\text { alternative when anyone centre reaches its } \\
\text { capacity. Food, dwelling facility, hygiene } \\
\text { set supplied. }\end{array}$ \\
\hline \multicolumn{3}{|c|}{ Preparedness } \\
\hline $\begin{array}{l}\text { Drill } \\
\text { Exercise }\end{array}$ & $\begin{array}{l}\text { Drill schedules based on need and } \\
\text { capacity, on annual basis. Last } \\
\text { March in Sultan Abu Bakar } \\
\text { dam/Susu dam. Siren activated; all } \\
\text { procedures followed. Simulations at } \\
\text { several dam water levels, informed } \\
\text { by TNB. }\end{array}$ & $\begin{array}{l}\text { The drill is on annual basis. While training, } \\
\text { SOP procedures were also learned. } \\
\text { Penghulu will help in training provided by } \\
\text { SSCC and District Office. Selangor State } \\
\text { Disaster Unit to instruct. Smart Regional } \\
\text { State Selangor focuses annual budget on } \\
\text { broadband internet. Information updated, }\end{array}$ \\
\hline
\end{tabular}


Mohd Zahari, M.Z., M. Zulkifli, N.A., Mohamad, M.R., Olabayonle, O.A., A. Kadir, N.A., Bachok, S.

Route Planning for Crowd Management in Disaster Prone Areas

\begin{tabular}{|c|c|c|}
\hline & $\begin{array}{l}\text { They need to make sure water } \\
\text { discharge is within the permissible } \\
\text { limit. } \\
\text { Meetings quarterly or biannually }\end{array}$ & $\begin{array}{l}\text { good network and accessible by small } \\
\text { villages. }\end{array}$ \\
\hline $\begin{array}{l}\text { Actions } \\
\text { during the } \\
\text { disaster, } \\
\text { important } \\
\text { documents }\end{array}$ & $\begin{array}{l}\text { During: Many documents were } \\
\text { missing; people panicking and not } \\
\text { listen to advice to relocate. Advise } \\
\text { to prepare the documents in safe } \\
\text { evacuation pack in a high place or an } \\
\text { elevated room, easy to reach and } \\
\text { keep documents in a plastic bag in } \\
\text { rafts by the river. } \\
\text { Allocated under MKN, Police as } \\
\text { operation commander initiate the } \\
\text { disaster control centre/room in the } \\
\text { Land and District Office. Land and } \\
\text { District Officer (DO) chair meeting: } \\
\text { members - OCPD, Fire Department. } \\
\text { Discussion, meeting among the } \\
\text { main agencies. Others only support } \\
\text { services. Areas impacted will be } \\
\text { zoned as Green, Yellow and Red } \\
\text { with limited or controlled access to } \\
\text { respective agencies. } \\
\text { Post-mortem and post-disaster } \\
\text { assistance: A follow-up. Investigate } \\
\text { all kinds of damages and fatality. } \\
\text { Assets ready, recognised the } \\
\text { location. An application for new } \\
\text { reconstruction for damaged houses. } \\
\text { If lost houses, provide a temporary } \\
\text { dwelling, assist in their daily } \\
\text { requirements, cash assistance. }\end{array}$ & $\begin{array}{l}\text { During: Selangor State Command Centre, } \\
\text { like Penang State Command Centre. Before } \\
\text { it rains, already informed, immediately. If } \\
\text { rain is accompanied by warning siren, } \\
\text { would alert head villagers. Council inform } \\
K R T \text {. } \\
\text { The Meteorological Department would } \\
\text { inform SSCC, which will inform DO. } \\
\text { Broadband is important. If the disaster } \\
\text { strikes in Sabak Bernam, a rural area with } \\
\text { lack of facilities, it will be problematic. If } \\
\text { flooding, relocate them as soon as possible. } \\
\text { If high tide, would be prepared. } \\
\text { Tried connecting the internet with the } \\
\text { Aboriginal villages but failed. Left with } \\
\text { wear and tear to rot, wastage of millions of } \\
\text { ringgits. If electricity is installed, not } \\
\text { reaching the village, they have to use petrol } \\
\text { which is expensive. Not only grid } \\
\text { connection (beam tower) but also power } \\
\text { supply. Heavy loads to carry. }\end{array}$ \\
\hline $\begin{array}{l}\text { Factors of } \\
\text { flooding }\end{array}$ & $\begin{array}{l}\text { Illegal encroachment of government } \\
\text { land but no longer occurring at an } \\
\text { alarming rate. } \\
\text { A case of fallen tree near Habu in the } \\
\text { year (2018). Not related to any } \\
\text { agricultural activity. Since land is } \\
\text { elevated and sloped, tendency to } \\
\text { result in soft soil, tree fell } \\
\text { perpendicular to the road. } \\
\text { Cultivation on hilltop without } \\
\text { installing proper technology for } \\
\text { irrigation. Haphazard water } \\
\text { irrigation overflown and leaking in }\end{array}$ & $\begin{array}{l}\text { Heavy rainfalls, long duration of rainfalls. } \\
\text { Storm water overflow and backflow when } \\
\text { the two drainages system are different size. } \\
\text { River overflow. } \\
\text { Dams for water sources, pollution by } \\
\text { economic activities. } \\
\text { Land and soil degradation due to mining } \\
\text { and mineral extraction, improper scheduled } \\
\text { waste disposal. }\end{array}$ \\
\hline
\end{tabular}




\begin{tabular}{|c|c|c|}
\hline & $\begin{array}{l}\text { Sungai Ikan. Overflow compounded } \\
\text { by heavy rainfall, impact slopes and } \\
\text { result in landslide. Man-made } \\
\text { disaster impact building, not the } \\
\text { illegal cultivation. }\end{array}$ & \\
\hline $\begin{array}{l}\text { Relocation } \\
\text { map }\end{array}$ & $\begin{array}{l}\text { Identified the hotspots, early } \\
\text { preparation and prevention planned, } \\
\text { followed by mitigation. Alternatives } \\
\text { actions. Access road. Determined } \\
\text { the tracks to identify possible } \\
\text { proposed alternative routes. } \\
\text { If emergency occurs, this will be the } \\
\text { route. Traffic is controlled and } \\
\text { diverted accordingly. }\end{array}$ & $\begin{array}{l}\text { Used maps to identify location of assets and } \\
\text { machinery from October until March. } \\
\text { Lorries stationed at PWD, prepared for } \\
\text { flooding, boats at Batu } 10 \text { and Sungai Serai. } \\
\text { No amphibian boats, only from the Federal } \\
\text { agencies, Council, CDA, SSCC. Trucks } \\
\text { traverse water up to hip high. }\end{array}$ \\
\hline \multicolumn{3}{|c|}{ Crowd Management } \\
\hline Siren & $\begin{array}{l}\text { Lembah Bertam Fire and Rescue } \\
\text { Department } \\
\text { Siren: short-yellow, long-red } \\
\text { Short siren for early warning and } \\
\text { long for emergency situation. The } \\
\text { lamp and lighting would be } \\
\text { necessary. }\end{array}$ & $\begin{array}{l}\text { Siren (flooding) in Pangsun, Sungai Serai, } \\
\text { Batu } 10 \text {. Volume and tone become higher, } \\
\text { if worsening. The sound is captured by the } \\
\text { SSCC's sensor. When siren activated, } \\
\text { inform MPKK, Penghulu to communicated } \\
\text { to people. }\end{array}$ \\
\hline Movement & $\begin{array}{l}\text { Movement follow directives. } \\
\text { Directive } 19 \text { is regarding SMART } \\
\text { team. SMART team only } \\
\text { operational at the federal level under } \\
\text { the purview of the Prime Minister. } \\
\text { Disaster has been categorised into } \\
\text { three types under } M K N 20 \text {, type } 1,2 \\
\text { and } 3 \text {. They will determine whether } \\
\text { no open the Command Room, and } \\
\text { types of assistance or what } \\
\text { mitigation plan to accommodate and } \\
\text { move people. }\end{array}$ & $\begin{array}{l}\text { If movement is still manageable, get } \\
\text { assistance from the Police Department to } \\
\text { evacuate. } \\
\text { DCW have counsellors to encourage } \\
\text { relocation and in event of death. DCW and } \\
\text { District Office Disaster Unit arrange } \\
\text { movement. Head village disseminate info } \\
\text { to locals, systematic, clear structure is clear. } \\
A D U N \text { also played roles. }\end{array}$ \\
\hline $\begin{array}{l}\text { Early } \\
\text { warning } \\
\text { system }\end{array}$ & $\begin{array}{l}\text { No advanced systems like Japan. } \\
\text { Just communication channels } \\
\text { through WhatsApp groups to set up } \\
\text { operation room. }\end{array}$ & $\begin{array}{l}\text { The Meteorological Department inform } \\
\text { SSCC Broadband is important. }\end{array}$ \\
\hline \multicolumn{3}{|c|}{ Rescue and Evacuation Route } \\
\hline
\end{tabular}


Mohd Zahari, M.Z., M. Zulkifli, N.A., Mohamad, M.R., Olabayonle, O.A., A. Kadir, N.A., Bachok, S.

Route Planning for Crowd Management in Disaster Prone Areas

\begin{tabular}{|c|c|c|}
\hline $\begin{array}{l}\text { Mapping the } \\
\text { routes }\end{array}$ & $\begin{array}{l}\text { Identified landslide hazards, risks, } \\
\text { locations, our needs, manpower, } \\
\text { assets and financial standing. } \\
\text { Cleared the area of flooding } \\
\text { damages immediately. The road } \\
\text { would not be blocked and not to } \\
\text { cause the landslide afterwards. A } \\
\text { new small fire station, in Brinchang } \\
\text { Lembah Bertam, by the RELA } \\
\text { building, towards Sg Koyan } \\
\text { identified flood-prone areas and } \\
\text { landslide risks. } \\
\text { Advanced mapping of the district of } \\
\text { areas prone to disasters needed. No } \\
\text { coordinated or comprehensive } \\
\text { mapping. Each agency prepares its } \\
\text { own mapping. Identified the } \\
\text { hotspots but not thoroughly. In a } \\
\text { utility map, aware of the location of } \\
\text { each utility and then run a } \\
\text { simulation. Need to see something } \\
\text { movable like video which good to } \\
\text { present to the public. Public Works } \\
\text { Department had prepared a video on } \\
\text { landslides but only the end results, } \\
\text { not the process. } \\
\text { Need alternative routes only just a } \\
\text { tiny kampong street, not a highway. } \\
\text { Concerned if landslides occurred } \\
\text { between Ringlet and Kampung } \\
\text { Raja. The only communication line } \\
\text { is through Jalan Simpang Pulai. }\end{array}$ & $\begin{array}{l}\text { There is a map on the Smart Selangor } \\
\text { Command Centre (SSCC) website, the map } \\
\text { is in real time. They have drone } \\
\text { surveillance to update report. There are also } \\
\text { siren and data on dams and rainfall } \\
\text { statistics. They are even updated in } \\
\text { midnight and wee hours. }\end{array}$ \\
\hline $\begin{array}{l}\text { Rescue } \\
\text { Route }\end{array}$ & $\begin{array}{l}\text { Access from (1) Tapah to Lipis, } \\
\text { from (2) Lojing area to Simpang } \\
\text { Pulai , from (3) Tanah Rata to } \\
\text { Ringlet, from (4) Kampung Raja to } \\
\text { Blue Valley Kuala Terlah, } \\
\text { Tringkap, Brinchang, Habu and } \\
\text { Lembah Bertam. } \\
\text { The travel time is on average: One } \\
\text { hour from Tapah ( } 61 \mathrm{~km}) \text { This is } \\
\text { original access road, one and half } \\
\text { hour from Gua Musang (122km), } \\
\text { Ipoh (90km) and Sungai Koyan } \\
\text { (110km) through highways/Federal } \\
\text { roads respectively. }\end{array}$ & $\begin{array}{l}\text { Good network of highways, federal, state, } \\
\text { district (PWD) and municipal roads. } \\
\text { LEKAS highway, PLUS highway. } \\
\text { Under Local Authority requirement, it } \\
\text { should be } 50-60 \text { feet road. Under Ministry } \\
\text { of Rural Development, } 20-30 \text { feet street is } \\
\text { sufficient. Logically, two passing vehicles } \\
\text { would need a minimum of } 40 \text { feet street. } \\
62 \text { traditionally Malay villages, } 12 \text { New } \\
\text { Villages for Chinese community, } 5 \text { Indian } \\
\text { communities, good access. } \\
\text { Also 10 Orang Asli (aboriginal) } \\
\text { communities (in Semenyih, Hulu Langa, } \\
\text { Gunung Nuang, Tekali, Dong Lai, Kacau }\end{array}$ \\
\hline
\end{tabular}




\begin{tabular}{|c|c|c|}
\hline & $\begin{array}{l}\text { The main road runs about } 40 \mathrm{~km} \text {. } \\
\text { Another is Tanah Rata to Ringlet } \\
\text { which traverses along } 14 \mathrm{~km} \text { route. } \\
\text { To Blue Valley is about } 24 \mathrm{~km} \text {. } \\
\text { Some forest tracks. Helipad is } \\
\text { aligned from the north to the south, } \\
\text { twelve in total, each with an access } \\
\text { by forest tracks. }\end{array}$ & $\begin{array}{l}\text { Dalam, Sungai Pening and Broga). The } \\
\text { aboriginals are directly under JAKOA. } \\
\text { Their area is disaster resilience. Rescue } \\
\text { route is resilient too. }\end{array}$ \\
\hline $\begin{array}{l}\text { Rescue } \\
\text { centre }\end{array}$ & $\begin{array}{l}\text { If no requirement for relocation, } \\
\text { only carry necessary actions. A } \\
\text { whatssapp group reports to the } \\
\text { District Assembly Member } \\
\text { (ADUN). Site visits by police, the } \\
\text { fire and rescue department, CWD to } \\
\text { determine the need for relocating the } \\
\text { population. Rescue centre opened } \\
\text { based on criteria: building condition } \\
\text { and safety, access road into higher } \\
\text { elevation, fire distinguisher and } \\
\text { toilets facilities. Also, calculations } \\
\text { of elevation, MCL, reverse the } \\
\text { probability of flooding incident, } \\
\text { ground permeability. } \\
\text { Relocating of people illness, } \\
\text { impairment and broken limbs. } \\
\text { Facilities need to be on the ground } \\
\text { floor and near the toilets. Normally, } \\
\text { centres are schools and other } \\
\text { buildings at higher ground. }\end{array}$ & $\begin{array}{l}\text { If situation warrants, open the evacuation } \\
\text { centre, feed the victims. When landslide } \\
\text { occurs, headcount for people working, at } \\
\text { home or outside the impacted area. Police } \\
\text { to evacuate, DCW counsellors to help } \\
\text { relocation, in event of death. } \\
\text { Rescue works are only carried out by CDA. } \\
\text { In rescuing people, PANTAS squad is } \\
\text { despatched. } \\
\text { Send the victims to CWD which in } \\
\text { identified centres. Head village help } \\
\text { designate a cook in green zones. Red zone } \\
\text { is for technical agencies which have assets } \\
\text { and expertise. DO prepared the food and } \\
\text { drinks, for the operation room. }\end{array}$ \\
\hline \multicolumn{3}{|c|}{ Factors Influencing Route Selection } \\
\hline $\begin{array}{l}\text { Existing } \\
\text { Main Route }\end{array}$ & $\begin{array}{l}\text { Limited networks. Access from } \\
\text { Tapah to Blue Valley. If emergency } \\
\text { occurs, that will be the route. To } \\
\text { make sure traffic is controlled and } \\
\text { diverted accordingly. Surrounded } \\
\text { by forests, need to preserve and not } \\
\text { degrade. }\end{array}$ & $\begin{array}{l}\text { Roads can be } 50-60 \text { feet road, some rural } \\
\text { areas } 20-30 \text { feet street. But } 40 \text { feet street } \\
\text { is sufficient. Kajang has good networks, in } \\
\text { and out of the city. }\end{array}$ \\
\hline $\begin{array}{l}\text { Existing } \\
\text { Alternative } \\
\text { Routes }\end{array}$ & $\begin{array}{l}\text { There is no alternative route for road } \\
\text { transportation. An alternative } \\
\text { conceived which is a similar design } \\
\text { to that of Rawang Bypass but } \\
\text { limited by monetary resources. The } \\
\text { route aligned by PWD, DID, } \\
\text { Forestry Department but yet to reach } \\
\text { compulsory land acquisition. }\end{array}$ & $\begin{array}{l}\text { Main road is the Protocol Road. This road } \\
\text { is utilised for official events where the } \\
\text { Sultan, the Chief Minister, the Prime } \\
\text { Minister or anything relating protocol, and } \\
\text { is under the maintenance of PWD. }\end{array}$ \\
\hline
\end{tabular}


Mohd Zahari, M.Z., M. Zulkifli, N.A., Mohamad, M.R., Olabayonle, O.A., A. Kadir, N.A., Bachok, S.

Route Planning for Crowd Management in Disaster Prone Areas

\begin{tabular}{|c|c|c|}
\hline $\begin{array}{l}\text { Proposed } \\
\text { Alternative } \\
\text { Routes }\end{array}$ & $\begin{array}{l}\text { There are proposed alternative } \\
\text { routes but still in confidentiality. } \\
\text { There are helipads but still in } \\
\text { confidentiality. No river/sea/water } \\
\text { routes. } \\
\text { Areas inaccessible, need boats, } 4 \times 4 \\
\text { vehicles. }\end{array}$ & $\begin{array}{l}\text { Various road networks and access points } \\
\text { but alternative routes can be very long/far. } \\
\text { If trapped, use the boats. No need of } \\
\text { helipads. }\end{array}$ \\
\hline $\begin{array}{l}\text { Socio- } \\
\text { economic } \\
\text { factors }\end{array}$ & $\begin{array}{l}\text { Largely Chinese communities, } \\
\text { cultivators and Aboriginals are } \\
\text { economic based community, need to } \\
\text { make money. No one in the right } \\
\text { mind would compromise this } \\
\text { income source. } \\
\text { No formal community participation } \\
\text { but invited them as observers. } \\
\text { The community is dependent on } \\
\text { tourism as economic sources. They } \\
\text { would not jeopardise their own } \\
\text { income by letting flooding destroy } \\
\text { their livelihood. }\end{array}$ & $\begin{array}{l}\text { Malay villages, New Villages for Chinese } \\
\text { community, Indian communities and } 10 \\
\text { Orang Asli (aboriginal) communities. } \\
\text { Aboriginal's area is disaster resilience. } \\
\text { Possess knowledge of selecting } \\
\text { settlements. Normal people organically } \\
\text { start their settlement by the river. } \\
\text { Aboriginals are highly aware of values of } \\
\text { the forest, economically. }\end{array}$ \\
\hline $\begin{array}{l}\text { Geo- } \\
\text { physical and } \\
\text { environ- } \\
\text { mental } \\
\text { factors }\end{array}$ & $\begin{array}{l}\text { Cameron is largely forest reserve. } \\
\text { Aboriginal communities are } \\
\text { excellent jungle trackers preferred } \\
\text { to select different safer routes. They } \\
\text { run upwards to the highland, good } \\
\text { knowledge medicinal herbs. } \\
\text { Community is familiar with the } \\
\text { highlands and urban settlement. } \\
\text { Access roads limited due to } \\
\text { geophysical nature. }\end{array}$ & $\begin{array}{l}\text { When electricity is installed over the } \\
\text { aboriginal's villages, they would claim the } \\
\text { trees belonged to them and have high } \\
\text { awareness about the environmental loss. } \\
\text { Some community are complacent. They } \\
\text { have knowledge of the access points of the } \\
\text { area and perceived water to recede within } \\
\text { couple of hours. }\end{array}$ \\
\hline
\end{tabular}

\section{RECOMMENDATION AND CONCLUSION}

Table 1 demarcated a few similarities between the two cases. These are associated with (i) dams that controlled the water discharge, (ii) heavy rainfalls, (iii) aboriginal resiliency, (iv) drill exercise, (v) MKN SOP, (vi) compounding landslide, (vii) mapping on 2D papers with no simulation runs and graphic presentation and (viii) a fully hierarchical set up at the three highest levels of administration. These findings concurred with those of Khalid and Shafiai (2015) as well as Mat Said and Ahmadun (2007). Other similarities are the lack of international best practice examples such as the non-existence of (ix) insurance scheme for protection against disasters (Linnerooth-Bayer \& Mechler, 2007).

Still, it was commendable for both cases (x) to establish rescue SOP, (xi) to set up relocation centre and (xii) to have the designation of Head of Village and 
Penghulu to manage the local population as well as to deploy (xii) drones for surveillance.

The differences between the two cases are (i) the geographical settings ( $\mathrm{CH}$ is highland, $\mathrm{HL}$ is lowland), (ii) access routes whereby $\mathrm{CH}$ has only four main routes which vulnerable to other disasters such as fallen trees and landslides. HL has a good network of roads. Both experienced (iii) land encroachment i.e. cultivation in $\mathrm{CH}$ while mining and illegal extraction and disposal of scheduled waste in HL. Another difference is that CH is planning for (iv) helipads due to non-existence of waterway networks. Whereas HL took advantage of its waterways by deploying amphibian boats. HL adopted developed countries strategies including (iv) the establishment of a command centre (SSCC) and (v) real-time map presentation on its website but the one $\mathrm{CH}$ had was not as advanced and sophisticated in terms of the use of technologies. HC asserted the need for simulation runs of disaster levels and impacts, to be presented in the $3 \mathrm{D}$ or $4 \mathrm{D}$ real-time mapping forms. There is a formally organised (vi) rescue squad at the state level (PANTAS in HL) but more voluntary set up of amateur and community-based CHAT organisation to share their $4 \times 4$ vehicles and radio communication in $\mathrm{CH}$.

It is therefore recommended that both the case study to look into the following strategies from the global best practices (Paudel, 2012). One is the (i) insurance scheme establishments. Next is the (ii) simulation runs for the possibility of impacted areas and prediction of disaster severity. Another area that can be learned is the (iii) early warning systems such as in Japan. Enactment of laws can also empower (iv) legislative foundation for the authorities at the lowest level to undertake management functions of disaster, should their areas be cut off from any communication. Finally, (v) empowerment of the local people, especially the organised and knowledgeable society members in decision making may increase the effective and efficiency of rescue and relocations strategies. In areas where (vi) aboriginals are plenty, it is good to take advantage of their expertise and experiences dealing with calamities in sustainable manners.

\section{ACKNOWLEDGEMENTS}

This study is funded by the Malaysian Government, under the Ministry of Higher Education. We would like to express our gratitude to the Fundamental Research Grant Scheme for the financial support of this research.

\section{REFERENCES}

Aini Mat Said and Fharul-Razi Ahmadun (2007) Disaster Management in Malaysia: Evolution, Development and Future Challenges, Jurutera, pp.11-14.

Bast, H., Delling, D., Goldberg, A., Müller-Hannemann, M., Pajor, T., Sanders, P., Wagner, D., \& Werneck, R. F. (2016). Route planning in transportation networks. In Algorithm engineering (pp. 19-80). Springer. 
Mohd Zahari, M.Z., M. Zulkifli, N.A., Mohamad, M.R., Olabayonle, O.A., A. Kadir, N.A., Bachok, S.

Route Planning for Crowd Management in Disaster Prone Areas

Chong, N. O., \& Kamarudin, K. H. (2018). Disaster risk management in Malaysia: Issues and challenges from the persepctive of agencies. Planning Malaysia, 16(5).

John. W. Handmer and Stephen R. Dovers (1996) A Typology of Resilience: Rethinking Institutions for Sustainable Development, Industrial and Environmental Crisis Quarterly Vol. 9 (4) pp. 482-511.

Khalid, M. N. A., \& Yusof, U. K. (2018). Dynamic crowd evacuation approach for the emergency route planning problem: Application to case studies. Safety Science, 102, 263-274. https://doi.org/https://doi.org/10.1016/j.ssci.2017.10.024.

Khalid, M. S. B., \& Shafiai, S. B. (2015). Flood disaster management in Malaysia: An evaluation of the effectiveness flood delivery system. International Journal of Social Science and Humanity, 5(4), 398.

Linnerooth-Bayer, J., \& Mechler, R. (2007). Insurance against losses from natural disasters in developing countries.

McEntire, D. A., \& Myers, A. (2004). Preparing communities for disasters: issues and processes for government readiness. Disaster Prevention and Management: An International Journal.

Mohamad Sukei Khalid and Shazwani Shafiai (2015) Flood Disaster Management in Malaysia: An Evaluation of the Effective Flood Delivery System, International Journal of Social Science and Humanity Vol. 5(4) pp. 398 - 402.

Mohd, S., Fathi, M. S., Harun, A. N., \& Chong, N. O. (2018). Key Issues In The Management Of The Humanitarian Aid Distribution Process During And PostDisaster In Malaysia. Planning Malaysia, 16(5).

Linnerooth-Bayer, J., \& Mechler, R. (2007). Insurance against losses from natural disasters in developing countries.

Paudel, Y. (2012). A comparative study of public-private catastrophe insurance systems: lessons from current practices. The Geneva Papers on Risk and Insurance-Issues and Practice, 37(2), 257-285.

Received: $15^{\text {th }}$ May 2020. Accepted: $1^{\text {st }}$ Sept 2020 